\title{
Legal Aspects of Stock Market Development in Ethiopia: Comments on Challenges and Prospects
}

\section{Abstract}

\author{
Jetu Edosa Chewaka *
}

Ethiopia lacks the institutional and legal frameworks that regulate the market for stock exchange, and in effect, the current stock trading activity may grow into a largely unregulated space in which everyone speculates and plays for short-term gains. Introducing stock market amidst the proliferation of companies in Ethiopia can thus benefit the economy. It is natural to expect that both companies under formation and investors in existing companies sell and transfer their shares to third parties giving rise to the availability of tradable shares in the market. This comment is a modest attempt to show the desideratum of introducing the legal and institutional frameworks governing stock market in Ethiopia. It tries to analyze the existing legal framework on stocks and tries to juxtapose relevant literature to give picture on the legal aspects of stock market development. In view of the potential advantage and the concerns raised by stock market development, I argue that devising legal infrastructure that accommodates stock market in Ethiopia is a timely issue to catch up with the global trend, given the current demand for stock trading as revealed by the over-the-counter markets.

\section{Key words}

Companies, over-the-counter, stock brokerage, stock market, Ethiopia

DOI http://dx.doi.org/10.4314/mlr.v8i2.7

\section{Introduction}

It is widely believed that stock markets have the potential to be powerful engines of economic growth in developing nations such as Ethiopia. ${ }^{1}$

\footnotetext{
* LLB, LLM, Lecturer of Law at the University of Gondar School of Law. Email: jetulaw@gmail.com. The writer is grateful to Professor Tilahun Teshome for encouraging and supporting me to write on this issue.
} 
Efficient stock market provides the public with investment opportunities and mobilizes savings, as well as international capital, for productive corporate financing. ${ }^{2}$ It is also argued that market forces serve to discipline management and public ownership thereby improving the accountability of the business sector. However, developing a robust and efficient securities regulation within which the stock market operates is a painstaking task for many developing countries. In this respect, the challenges squarely recline on designing the legal frameworks capable of protecting the investor, preventing systemic crises and promoting the market they govern. ${ }^{3}$

In the Ethiopian context, the historical development of stock market traces its roots back to the Imperial period. During this time, Ethiopia managed to develop the institutions of stock market, such as the "Addis Ababa Share Dealing Group". However, after the demise of the Imperial regime, the stock market was abolished due to the introduction of command economy. ${ }^{5}$ Since then, except Commodities Market Exchange for agricultural products under the current regime, no stock market has been legally designed to trade stocks except for the fragmented and unregulated stock trading in a dealer market. Presently, although the economic system is suitable for the stock market to flourish, the desirability of having stock market is, however, hotly debated on both official and non-official circles. ${ }^{6}$ In the media, there is discourse regarding the slow pace and low level of government interest in pursuits toward designing a legal framework that regulates the establishment and operation of stock market. ${ }^{7}$

\footnotetext{
${ }^{1}$ John Fagan, The Role of Securities Regulation in The Development Of the Thai Stock Market, (2002-2003) Columbia Journal of Asian Law, Vol. 16, p. 305.

${ }^{2}$ Ibid.

${ }^{3}$ Ibid.

${ }^{4}$ Ruediger Ruecker (2011), "Market Potential Assessment and Road Map Development for the Establishment of Capital Market in Ethiopia," (Private Sector Development Hub/Addis Ababa Chamber of Commerce and Sectoral Associations), p. 1

${ }_{6}^{5}$ Ibid.

${ }^{6}$ The chief Economist and vice president of African Development Bank, Professor Mthuli Ncube, recommended that "it is the right time for Ethiopia to invest on the necessary infrastructure that will enable it to introduce stock market. This will enable the country to mobilize capital and encourage savings." He noted that it does not matter who owns it. But, the modern way of introducing stock market is by setting up a company formed in public-private-partnership. See New Business Ethiopia Reporter, "Africa Development Bank Recommends Stock Market to Ethiopia," available at $<$ www.newbusinessethiopia.com> (Accessed on May 20, 2013).

${ }^{7}$ Ibid.
} 
Against this backdrop, this comment briefly deals with stock market and its legal aspects in Ethiopia. It does not comprehensively cover stock market regulation, but raises some legal aspects of the stock market given the steadily increasing magnitude in the performance of financial institutions in Ethiopia. Sections 1 and 2 highlight some concepts of stock market development in general and in Ethiopia in particular. The third section discusses the current need for stock market in Ethiopia and its major challenges. The last two sections briefly examine the legal aspects of stock market development and highlight the attempts made by the business community and the government to crystallize its legal and institutional frameworks.

\section{The Concept of Stock and Stock Market: A General Overview}

The term stock can be defined as "the capital or principal fund raised by a corporation through subscribers' contributions or the sale of shares". ${ }^{8}$ Stock represents a share of ownership in a corporation. ${ }^{9}$ By and large, such kinds of stocks could be identified as security representing equity claims on the earnings and assets of the corporation. In this comment, the term stock is used interchangeably with the term share.

Stocks are generally traded in stock market. Stock market refers to capital market in which stocks of corporations are sold to investors. ${ }^{10}$ In simple terms, it is a market place where equity interests are exchanged either at par value, premium value or for less than the par value - also called discount stock. ${ }^{11}$ Thus stock market allows stockholders (shareholders) to transfer to another investor when they want to sell their stocks.

It should be noted that stocks could be sold and bought in primary capital market. In primary markets, new business can start by obtaining funds directly from households in which new stocks are sold to investors via the

\footnotetext{
${ }^{8}$ Black, Henry C. (1991), Black's Law Dictionary, (6th ed), West Publishing Co. St. Paul.

${ }^{9}$ Mishkin, Frederic S. (2004), The Economics of Money, Banking, and Financial Markets $7^{\text {th }}$ ed.(The Addison-Wesley Series in Economics, p. 5.

${ }^{10}$ Ibid.

${ }^{11}$ Yuwa Wei (2005), "The Development of the Securities Market and Regulation in China," Loyola of Los Angeles International and Comparative Law Review, Vol. 27, p. 486.
} 
mechanism of underwriting. ${ }^{12}$ The selling of common stock to the public through Initial Public Offering (IPO) in the primary market is an instance whereby widely held share companies under formation offer new shares to the investors. ${ }^{13}$ It is vital not to lose sight of the fact that secondary markets play an important role in the regulation of initial public offering of shares through the listing standards, subject to the discretion of stock exchanges. ${ }^{14}$

On the other hand, in the secondary market, existing stocks are sold and bought among investors or traders in the stock market through stock exchange. Furthermore, secondary market could be either auction market or dealer market. While the stock market is part of an auction market, over-thecounter (OTC) is part of the dealer market. The difference between stock market and OTC is that the former exchange market operates in a structured manner and physical facility with a trading floor to which all stock transactions are supposed to be directed. ${ }^{15}$ However, OTC market traditionally operates in unstructured manner without any physical facility in which any qualified firm freely engages in the transactions of stocks.

At this juncture, it is also vital to differentiate bond and stock. Bond is a security instrument which is used either by the government or any other corporation to raise funds in the bond market. ${ }^{16}$ Unlike stock which as indicated before is an equity instrument, bond is a debt security evidencing that a promise has been made by a government such as Treasury Bills (TBills) or by corporation such as debenture to pay a specified amount of money in recognition of a loan to the business. ${ }^{17}$ Like stock, a bond is another way of obtaining funds but this time "representing funds borrowed by the corporation or the government from the holder of the debt obligation". It should be noted that both stock markets and bond markets are categories of capital market. Like stock market, bond market helps bond

\footnotetext{
${ }^{12}$ Mebrahtu L. Teklehaimanot (2014), "Is Ethiopia Ready to Commence Capital Market? Analysis of Potential Beddings, Constraints and the Dubious", International Journal of African and Asian Studies - An Open Access International Journal Vol. 3.

${ }^{13}$ For more in-depth discussion on IPOs see generally Tikikile Kumulachew (2011), Regulation of Initial Public Offering of Shares in Ethiopia: Critical Issues and Challenges (AAU LLM Thesis).

${ }^{14}$ Christiansen, H. Koldertsavo (2009), "The Role of Stock Exchanges in Corporate Governance", Financial Market Trends (OECD), p. 5.

15 Ratner, D. (1980), Securities Regulation Material for a Basic Course, ( 2nd Ed, USA, West Publishing Co. p. 2.

16 Peter S Rose (1986), Money \& Capital markets: The Financial System in the Economy 2nd edition, p. 556.

${ }^{17}$ Black, supra note 8 .
} 
holders to transfer their bond to third party when they want to sell it in the secondary market or use it as collateral to get loan from banks. As the title indicates, this comment deals with stock market in the context where corporations or individual investors sell and buy shares and hence will not deal with bond and bond markets. But it should be noted that some literature generally use stock market to include the trading of also bonds. ${ }^{18}$

In brief, a stock market is an open market place which provides facilities for stock brokers, investors and corporations to trade in stocks. Stock markets generally provide the means by which companies raise capital to start new business or expand the existing business by offering new stocks to the public. It also provides a trading facility for investors to sell their share ownership in corporations. Unlike the bond market, stock market provides an opportunity for companies to finance their business through equity investment. The following section highlights the trends and desirability of stock markets in Ethiopia.

\section{The Trends of Stock Market Development}

During the Imperial Regime, there was a small share trading activity in Ethiopia carried out under the regulatory auspices of National Bank of Ethiopia (NBE), department of Share Exchange. ${ }^{19}$ The NBE also allowed other financial institutions and few private share dealers to participate in shares trading, particularly related to facilitation of transaction of shares and other services in the share markets. For instance, the Addis Ababa Share Dealing Group was one of the private share dealing groups which served as the connecting link for buyers and sellers in an auction process. ${ }^{20}$ Moreover, financial institutions such as Addis Ababa Bank, the Commercial Bank of Ethiopia and the Ethiopian Investment Corporation played an intermediary role in transferring and delivery of traded shares in the form of over-thecounter share dealing services. ${ }^{21}$

According to Von Pischke, Ethiopian stock market during the Imperial regime was moderately successful in its pioneering efforts to provide an organized market for companies whose shares were relatively widely held

\footnotetext{
${ }^{18}$ Yishak Mengesha (1998), "Prospects for a Securities Market in Ethiopia," Ethiopian Journal of Economics, Vol. VII, No. 1, p. 91.

${ }^{19}$ Ruecker, supra note 4.

${ }^{20}$ Tiruneh Legesse (2012), "Establishing Financial Markets in Ethiopia: the Environmental Foundation, Challenges and Opportunities", Journal of Business and Administrative Studies, Vol. 4 No. 1, p. 2

${ }^{21}$ Ibid.
} 
companies despite limited participation of the public and investors to invest in stocks. ${ }^{22}$ Pischke noted that though market capitalization remained small and did not have much impact on the economy, workable share trading environment had been developed. ${ }^{23}$

With the coming of the Dergue regime to power, the introduction of a centrally planned economy resulted in the nationalization of private industries and dissolution of share dealing groups. ${ }^{24}$ Hence, due to state ownership and control of major economic activities, there was no fertile environment for stock market development from 1975 to 1991 . The post1991 government of Ethiopia has introduced an economic system which encourages the private sector, which is expected to play a critical role in Ethiopia's economic development. Under the current regime, although major economic sectors are still dominated by the state, various financial and nonfinancial business sectors are open to private investors. Both private and state owned financial business organizations (banks, insurance and microfinancial institutions) are closely regulated by the $\mathrm{NBE}{ }^{25}$ Hence, the more financial institutions and business organizations proliferate in Ethiopia, the more would tradable shares be available at the market.

Despite the growing interest of the private sector to operate the business of stock trading, the government seems to be overcautious. For example, the late Prime Minister Meles Zenawi had officially challenged the desirability of introducing stock market in Ethiopia. In 2011, he had said:

At the current stage, there is no need for a stock market in the country. Although the government is not against a stock exchange system in the country, its primary focus is on developing the banking system and

22 J.D. Von Pischke (1968), Share and Share Trading in Addis Ababa, (Haile Selassie I University, Addis Ababa.

${ }^{23}$ Ibid.

${ }^{24}$ Asrat Tessema (2003), "Prospects and Challenges for Developing Securities Markets in Ethiopia: An Analytical Review," R\&D Management , Vol. 15, No. 1 (Blackwell Publishing Ltd, USA), p. 52.

25 It should be noted that other non-financial business organizations are also proliferating more than the financial business organizations. However, as almost all of these non-financial private limited companies are closely held by one person or sleeping members constituting either spouse, families or relatives, it could be difficult, though not impossible to expect the transfer of shares to outsider which makes it less appealing to trading of stocks in such business organizations. See Nigusie Tadesse (2000), "Major Problems Associated With Private Limited Companies in Ethiopia: the law and the practice” (LLM Thesis, AAU, p. 97. 
developing the commodity exchange of agricultural products in rural areas. $^{26}$

Based on such assumption, instead of introducing stock market, the government introduced the Ethiopian Commodity Exchange (ECX) in 2008 as a structured market facility designed to provide fair and transparent pricing of major agricultural products. Hence, in the absence of officially structured market place for trading shares, investors and companies are forced to sell their share through bidding process or through brokers.

In the absence of well structured and regulated stock market, the unregulated and unstructured OTC dealer market for share trading would ultimately reign with all its eventualities. ${ }^{27}$ The question is therefore, whether the lack of interest on the part of government to introduce stock market is justified in the face of staggering reality of share trading and share issuing of companies in Ethiopia.

\section{The Need for and Challenges in Introducing Stock Market in Ethiopia}

Studies show that stock market can benefit the economy of a developing country in a number of ways, particularly when prices fairly and accurately reflect supply and demand. ${ }^{28}$ First, companies with prospective growth potential will be able to raise equity capital, forcing banks to compete to supply the same financing. Second, the public issuance of shares can provide precious investment resources for enterprises that do not have enough retained earnings or which are unable, or unwilling, to go to the banks. ${ }^{29}$ Third, in addition to acting as a source of finance, the stock market also

\footnotetext{
${ }^{26}$ Muluken Yewondwossen (2013), National Bank of Ethiopia Looks into Stock Market $<$ http://www.capitalethiopia.com/index.php?view=article\&id=3635:nbe-looks-intostock-market-\&format=pdf $>$

${ }^{27}$ For example Ethiopian Potash Corporation, a Canadian company based in Toronto, Ontario, and Addis Ababa, Ethiopia recently announced that it has commenced the application process for listing on the OTCQX (the premier tier of the U.S. Over-theCounter market). The Company also announced that as has been previously disclosed in its Information Circular and RTO filings, the Company had, on April 11, 2011, an aggregate of 17,368,726 common shares ("Common Shares") of EPC in connection with the satisfaction of the "First Milestone" under the option agreement (the "Option Agreement") between EPC, G and B Central African Resources Ltd. See at $<$ http://www.ethiopian-news.com/ethiopian-potash-applies-for-listing-on-the-otcqx/>

${ }^{28}$ Yishak Mengesha, supra note 18, at p. 85.

${ }^{29}$ Stephen Green (2003), China's Stock market: A Guide to its Progress, Players and Prospects (London, The Economist Newspaper Ltd, p. 3.
} 
offers firms the opportunity of varying the costs and risks of their financing structures, potentially insulating them from higher interest rates and a credit crunch. ${ }^{30}$ Fourthly, introducing stock markets enhances the liquidity of assets as it provides high level of buying and selling stocks without affecting its market price. Hence, in the absence of stock market facility, the ability to convert stocks into cash quickly could be hampered. Finally, the market can also play a role in facilitating long-term asset management such as private insurance and pension funds. ${ }^{31}$

Studies conducted in the Ethiopian context show that introducing stock market, among other things, allows the "de-concentration of ownership, improve accounting and auditing standards, provide effective tools for monetary and fiscal policy and help privatization efforts". ${ }^{32}$ Another study also states that the establishment of stock market in Ethiopia could contribute to economic growth, since it encourages investment by helping traders buy and sell stocks quickly and efficiently. ${ }^{33}$ Hence, absence of stock market in Ethiopia may cause illiquidity of assets as holders of stocks may find it difficult to sell same at a fair market price. Specifically, as Ethiopian investors only have a small portion of their household income to invest, a fair priced stock trading is significant in order to avoid creating systematic losses for the general public. Consequently, in order to ensure the liquidity of assets in Ethiopia, it is vital to introduce stock market because of the limited investor and issuer base. ${ }^{34}$

However, a stock market does not automatically provide any of the indicated benefits. This is because it relies on an array of institutions for its benefits to be realized. For instance, institutions, such as a free press, an efficient and independent judicial system, corporate lawyers and accountants, professional underwriters and a group of mature institutional investors are difficult to establish at an early stage of economic development. ${ }^{35}$ Without an independent and impartial investigative press and in the absence of adequate and enforced laws, companies will tend to

\footnotetext{
${ }^{30}$ Ibid.

${ }^{31}$ Ibid.

${ }^{32}$ See generally Asrat Tessema (2003), "Prospects and Challenges for Developing Securities Markets in Ethiopia: An Analytical Review", African Development Review, Vol. 15 No. 1 pp. 50-65.

${ }^{33}$ Abebe Yitayew (2006), "An alternative to Term-Loan Financing on the Horizon, its development dubious: securities market, the missing link", Ethiopian Journal of Accounting and Finance, Vol. 1 No 1, p. 33.

${ }^{34}$ Ruecker at supra note 4.

${ }^{35}$ Id. at p. 14.
} 
defraud thereby impacting investor confidence which is a tenet of stock market development. In the absence of reliable corporate disclosures, trading in immature stock markets may often take place on the basis of rumor. If, in addition, a government lacks the ability, or the will, to create or enforce laws that protect small investors, then insider dealing and price manipulation is likely to be common. For these reasons scholars underline the need for an efficient banking system which is better equipped at valuing businesses and monitoring their use of capital a relatively greater priority rather than stock market for a developing economy such as Ethiopia. ${ }^{36}$

Yet the outright rejection of stock market is not a prudent option for Ethiopia as uncoordinated share trading is a common place. Thus, the issue is whether the challenges that relate to the absence of legal and institutional guidance regarding share trading in Ethiopia can be addressed because the advantages in introducing a stock market seem to outweigh these challenges. Studies show that shareholders in widely held companies face the difficulty to get the buyer easily and sell back their shares at a fair price. ${ }^{37}$ Shareholders in non-financial companies with low profit margin face the challenge of higher commission by the brokers to sell back their shares while shares of financial companies were facilitated by insider trading in which brokered shares were traded for clients on their own account. ${ }^{38}$ The current limited facilities of the OTCs market in Ethiopia cannot cope with rapidly growing demand as share prices are uncoordinated between counters thereby facilitating arbitrage and manipulation.

Therefore, absence of centralized registration for share certificates and illegal stock trading may grow into a largely unregulated space thereby posing stock investment risks and impacting the benefits of stock markets. It is noted that when everyone is speculating and playing for short-term gains, a stock market has little economic benefit. ${ }^{39}$ It does not channel capital towards good-quality firms or productive investments; it does not discipline

\footnotetext{
${ }^{36}$ Ibid.

${ }^{37}$ Ahferom Teklay (2011), Should Ethiopia Consider Establishing of a Stock Exchange? (AAU MBA Thesis) p. 53.

${ }^{38}$ The public expectation of buying shares in financial institutions such as banks and insurance is very high due to their profitability. The most compelling reason is that the legal and institutional frameworks for the regulation of financial institutions in Ethiopia is well regulated by the NBE where financial risks are if any are addressed at the earlier possible time. For more information see Gazena Erchafo (2001), Monetary Policy Instruments in Ethiopia (Economic Research Department, National Bank of Ethiopia) pp. 1-18.

${ }^{39}$ Ibid.
} 
managers participating in insider trading. And where public funds are involved, it can have damaging consequences for the government's finances. In short, a stock market can have a deleterious impact on a country's economy and its corporate development unless a prudent regulation is designed. Yet, lack of such regulation does not undermine the positive role of stock market in the enhancement of saving and investment because the regulatory challenges that inhibit its effectiveness can be addressed.

In a nutshell, access to and ease in exchange of stock fundamentally influences the prospects for private sector development in Ethiopia. The extent to which existing firms raise funds by trading stocks, the willingness of households to invest in assets, and the ability to allocate their assets freely represent all the necessary conditions for the development of stock market in Ethiopia as an engine of economic development.

\section{The Trading of Share Ownership in Companies}

The development of stock market envisages the existence or introduction of robust and prudent legal framework and institutions. Currently, there is no specific legislation that regulates the exchange of securities in Ethiopia other than the possibility of a closer look into the Commercial Code of 1960, which is still the core legal instrument which regulates the formation and operation of business activities. Generally, without prejudice to the enactment of a specific law that regulates stock trading in Ethiopia (in the foreseeable future), we can note two aspects of stock trading in Ethiopia, i.e., (1) the legal aspects of trading share ownership in corporations, and (2) the legal frameworks that regulate stock market. The 1960 Commercial Code considers shares of companies as tradable financial security instruments irrespective of the existence of structured stock market in Ethiopia. It is thus imperative to critically reflect on some legal aspects of stock trading under the Commercial Code.

One of the basic features of a company in the course of business operation is the nature of share transferability. By allowing the transferability of shares, the perpetuity of a company is achieved at least for a relatively long period of time. Although shares are types of transferable security instruments, their ownership in a company does not automatically confer tangible rights in property. ${ }^{40}$ According to the Ethiopian Commercial Code, every share "shall confer a right to participation in the annual net

${ }^{40}$ Ratner, D. (1980), Securities Regulation Material for a Basic Course, (USA: West Publishing Co, $2^{\text {nd }}$ Ed.), p. 1. 
profits and to a share in the net proceeds on a winding up" ${ }^{41}$ As such, the only tangible rights to property that result from stock ownership exist in the event of a company's dissolution and liquidation. Hence shares in a company have no intrinsic value in themselves but represent rights in ownership whose value depends on the financial condition, and the profitability or future prospects of the corporation who issued the stock. ${ }^{42}$

Under the Ethiopian Commercial Law one can identify two forms of shares. ${ }^{43}$ The first and most common form of share in Ethiopia is a share that is registered in the name of the shareholder. The second form of share is bearer share. As the name indicates, bearer shares are assigned by delivery without any other requirement. A bearer share may be transferred by simple delivery of the instrument. Therefore, in the absence of any evidence to the contrary, bearer shares shall be deemed to be the property of the holder for the purpose of payment of dividends, redemption and right of participation in general meetings. ${ }^{44}$ It should be noted that issuing of bearer share in Ethiopia may be prohibited by law or Memorandum or Articles of Associations. ${ }^{45}$ Although bearer shares are not common in Ethiopia, the legal prohibition that relates to their transfer applies in the banking business. According the Banking Business Proclamation No. 592/2008, only the transfer of registered shares is allowed and "any transfer of shares that is not recorded in the register of share shall be null and void". 46

The other issue that relates to share trading is the pricing of shares. Shares may not be issued at a price lower than their par value, although companies are at liberty to issue shares at price greater than their par value where it is provided in the memorandum of association or decided by extraordinary general meeting. ${ }^{47}$ The price difference at which shares are issued and the par value is called a premium value. ${ }^{48}$

Another relevant legal aspect of stock trading for the development of stock market in Ethiopia is the potential availability of company stocks at the market. In this regard, the availability of stock for trading emanates from two main legal sources. The first emanates from the initial public offering

\footnotetext{
${ }^{41}$ The Commercial Code of the Empire of Ethiopia of 1960, Nagaret Gazeta, Extra ordinary Issue, No. 3 of 1960 (henceforth The Commercial Code) Art. 345.

${ }^{42}$ Ratner, supra note 40 , at $\mathrm{p} 2$.

43 The Commercial Code, Art.325.

${ }^{44} I d .$, Art. 340.

${ }^{45}$ Id. Art. 325.

${ }^{46}$ Banking Business Proclamation No. 592/2008, Art. 10(4).

${ }^{47}$ The Commercial Code, Art.326.

${ }^{48}$ Ibid.
} 
(IPO) of shares by the company. ${ }^{49}$ It should be noted that private limited companies are not allowed to offer shares to the public to start business although it may be incorporated with a maximum of fifty shareholders. ${ }^{50}$ Hence, any reference to IPO of shares in this comment relates to companies limited by shares. But this does not necessarily mean that the IPO of shares is a mandatory requirement to incorporate share companies as it could be possible to incorporate same with minimum capital contributions obtained from five founding members. The second source of tradable stock emanates from the sell back of stocks in the secondary market.

The initial public offering (IPO) of shares provides a facility where investors can get first access to newly issued stocks of companies. The main objectives of incorporating Share Company through the IPO of shares is its advantage of mobilizing huge cash proceeds from the sale of stock to finance large scale business activities. In order to offer shares to the public, founders of a share company to be established by public subscription are required to obtain the written permission of the registering office in advance. $^{51}$

The second legal basis of tradable stock, as mentioned above, emanates from the sell back of shares by the shareholders or the issuance of new shares by a share company whose capital is fully paid up. ${ }^{52}$ In the former instance, the Commercial Code provisions (of both private limited companies and share companies) allow shareholders to transfer their shares to third parties. ${ }^{53}$ Moreover, the Commercial Code clearly enables a shareholder to withdraw from the company by selling shares at the average price on the stock exchange over the last six months. ${ }^{54}$ If the shares are not quoted on the stock exchange, the shares are sold at a price proportionate to the company's assets shown in the balance sheet of the last financial year. ${ }^{55}$ The latter instance of stock trading relates to the situation in which a share company whose capital is fully paid issues new shares to further increase its capital. $^{56}$

${ }^{49}$ Id., Art. 317-322.

${ }^{50}$ Id., Art. 510(2).

${ }^{51}$ The Commercial Registration and Business Licensing Proclamation No. 686/2010, Art. 12(5).

${ }^{52}$ See Commercial Code Art. 464.

${ }^{53}$ Id., Arts. 333 and 523.

${ }^{54}$ Id., Art. 463.

${ }^{55}$ Ibid.

${ }^{56}$ The Commercial Code, Arts. 464 and that follow. 
In addition to providing the legal basis for the possibility of stock trading in the stock exchange, the Commercial Code also entrusts 'stock brokers' as commission agents who legally deal with the selling and buying of stocks on behalf of the principal or any other person. ${ }^{57}$ In the face of the legal basis for the potential tradability of stocks in Ethiopia, the important issue that remains at large is whether it is prudent to remain silent regarding the regulatory issues of subsequent share transactions. The following section briefly discusses the challenges and prospects of designing legal and institutional frameworks and the attempts made so far to establish stock market in Ethiopia.

\section{The Legal and Institutional Challenges and Prospects of Introducing Stock Market}

Despite the legal basis of potential tradability of shares in Ethiopia, the Commercial Code and the subsequent proclamations fail to provide legal and institutional frameworks for the prudent regulation of subsequent transactions of shares in an open market. There is no rule that sets the standard and requirements for listing and delisting of companies stock in the market. Thus, share issuing companies are operating traditionally under unregulated market. According to a capital market consultant, Ruediger Rucker, "the current situation of share issuing may threaten the prospect of capital market formation in Ethiopia. It may erode public credibility towards capital market in case of default". 58

Thus, the pertinent question is how could Ethiopia harvest any perceived economic advantage from the stock exchange in the absence of legal and institutional frameworks that regulate stock market? Particularly, in the absence of mandatory disclosure requirements, shareholders could be deprived of the right to be informed and get relevant and timely information regarding the selling and buying of shares. Hence, inadequate rules on the supervision and regulation of stock trading may engender fraudulent brokerage in the process thereby affecting public confidence.

Developing domestic stock market involves addressing, even in the embryonic stages, legal, regulatory, and supervisory framework in order to

\footnotetext{
${ }^{57}$ Id., Art. 62

${ }^{58}$ See Ethiopia's Struggle for a Capital Market," Available at:

$<$ http://www.ethiopiainvestor.com/index.php?view=article\%3B\&catid=69\%3Aarchiv es\&id $=2195 \% 3$ Aethiopias-struggle-for-a-capital-market-

$\&$ format $=$ pdf\&option $=$ com_content $>$.
} 
ensure transparency and predictability for investors. ${ }^{59}$ An early step in developing stock market regulation to support the issuance and trading of stocks is to establish a legal framework for its issuance. ${ }^{60}$ There is also a need to develop a regulatory environment that fosters market development and enables the enforcement of sound supervisory practices. ${ }^{61}$ In particular, market regulation should ensure that secondary market trading is conducted in a transparent and efficient manner. Therefore, an important component of the legal and regulatory framework is required to assure the provision of adequate information such as the requirement of information disclosure, prohibition of improper trading practices - insider trading, fraud, and market manipulation. ${ }^{62}$

A study conducted under the auspices of Private Sector Development Hub/Addis Ababa Chamber of Commerce and Sectoral Associations has identified legal and regulatory infrastructure as preconditions for the development of stock market in Ethiopia. ${ }^{63}$ Among other things, the need for a regulatory organ and securities enforcement, adequacy of judicial system, accounting and auditing standards, corporate governance, takeover and merger regulation, and bankruptcy and insolvency law are among the significant aspects of the legal regime ${ }^{64}$ that should be addressed. Despite the promising prospects of stock market in Ethiopia, its legal and institutional frameworks are considered as "long overdue". 65 It is thus important to rectify the loss of interest on the part of Ethiopian Government in designing legal and institutional frameworks to regulate stock markets.

Spearheaded by group of entrepreneurs organized as the "Ethiopian Share Dealing Group" under the Addis Ababa Chamber of Commerce and Sectoral Associations, there was an initiative to establish a share dealing group

\footnotetext{
${ }^{59}$ Robert E. Litan, et al. (editors), The Future of Domestic Capital Markets in

Developing Countries (The Brookings Institution Press Washington, D.C. 2003), p.49 ${ }^{60}$ Ibid.

${ }^{61}$ Ibid.

${ }^{62}$ Bernard S. Black, "The Legal and Institutional Preconditions For Strong Securities Markets," UCLA Law Review, Vol 48, (2001), p 783. Market manipulation may "usually involves an attempt to drive up a stock price on the secondary market by creating demand for the stock through the dissemination of false and misleading information. A number of strategies could be exercised to achieve the purpose of market manipulation, including pools, churning, runs, and short selling." See Yuwa Wei, supra note 11, at p. 487.

${ }^{63}$ Ruecker, supra note 4 , p. 27

${ }^{64}$ Ibid.

${ }^{65} \mathrm{Id}, \mathrm{p} .38$
} 
similar to the former, Addis Ababa Share Dealing Group. ${ }^{66}$ This initiative included an attempt to develop rules and regulations as well as bylaws of a share dealing group. The model rules and regulations manual, inter alia, consists of: rules regarding membership requirements; Listing Rules; Requirements for Insurers; Listing of shares; Listing of Bonds; Trading Rules and Rules for clearing and Settlement of Stock Exchange Transactions. ${ }^{67}$ But, this commendable effort by the private sector to "reinvent the wheel" or "re-launch" share dealing has not been endorsed or supported by the Ethiopian government. Even though attempts are made to study the potentials for the development of stock market by the National Bank of Ethiopia, the commitment on the part of the government is still marginal.

It is widely argued that although the government seems to be aware of the merits of having a stock market, there is the assumption that stock market might not contribute to the short-term development of the country. Rather it is discerned that the government is preoccupied in strengthening the Ethiopian Commodity Exchange (ECX) to enhance fair and transparent pricing of major agricultural products. Moreover, some argue that the ongoing issuance of debt instruments (bond) by the government for state financing seems to have induced disinterest on the part the government in alternative investment options or capital market competition. ${ }^{68} \mathrm{We}$ can borrow a phrase from Keynes who figuratively referred the stock market as "nothing else than legalized casino"69. But this cannot be considered as a literally serious statement in policy making. On the contrary, there is the risk that further delay in the legal framework and the persistence of various difficulties in Ethiopia's under-regulated capital market can steadily erode credibility and entrench negative public perception regarding stock acquisition and exchange, thereby adversely dwarfing stock markets during their take-off phases. There is thus the need for strong commitment of government towards the legal developments for stock market in Ethiopia.

${ }^{66} I d$, p. 2

${ }^{67}$ Ibid.

68 According to information learned by Capital, A weekly Business Magazine in Ethiopia, a new directive from the National bank of Ethiopia creates secondary markets for bond trading which also apply to government bonds issued to Citizens to finance the "Ethiopian Grand Renaissance Dam". See "Secondary Market on Board for Bond," at <www.ethiopianinvestor.com>

${ }^{69}$ Quoted in Caporaso, J. and D. Levine (1992, Theories of Political Economy, (New York: Cambridge University Press), p. 111. 


\section{Concluding Remarks}

Stock market has long been considered as a vital instrument for an efficient and modern financial market. In stock markets, shares are sold by and transferred from one investor to another thereby enhancing liquidity. The history of stock markets shows that the only way to create liquidity was, for investors to meet at a fixed place regularly to ensure stock exchange. In developed countries such as the USA, a big swing in the prices of shares in the stock market is always a big story on the evening news. People often speculate on where the market is heading and get very excited and engaged in the process. The attention the market receives can probably be best explained by one simple fact: It is a place where people can get rich -or poor-quickly. This very fact shows how unregulated stock market exacerbates the problems associated with it. That is why regulation of stock markets is indeed a sine qua non condition for its effective and efficient operation.

In the context of Ethiopia, the absence of institutional, legal and policy framework for stock market activity, may adversely affect liquidity thereby adversely impacting economic development. There is lack of commitment on the part of the government to establish prudent regulatory infrastructure thereby hampering Ethiopia's stock market development. In the absence of interest of the government to facilitate the emergence and coalescence of stock market, the current stoke brokerage in out of the counter (OTC) market unfolds, and much work is bound to be required in the future to address the problems associated with such dealer markets. Even worse, the present unregulated market for stock exchange in the OTC market may severely affect public confidence up to a level which can be counterproductive against future pursuits toward a strong, reliable and efficient stock market. This indeed impedes the development of stock market and dwarfs down its role in the Ethiopian economy unless prudent regulation is put in place. 